\title{
Potential of Nanocarrier-Based Drug Delivery Systems for Brain Targeting: A Current Review of Literature [Corrigendum]
}

\author{
Alotaibi BS, Buabeid M, Ibrahim NA, et al. Fax +92 992-383441 \\ Int J Nanomedicine. 2021;16:7517-7533. \\ Email gmdogar356@gmail.com \\ The authors have advised Correspondence section on page \\ Manal Buabeid \\ 7517 should be: \\ Tel +97 1503602776 \\ Email m.buabeid@ajman.ac.ae
}

Correspondence: Ghulam Murtaza

Tel +923215129950

\section{Publish your work in this journal}

The International Journal of Nanomedicine is an international, peerreviewed journal focusing on the application of nanotechnology in diagnostics, therapeutics, and drug delivery systems throughout the biomedical field. This journal is indexed on PubMed Central, MedLine, CAS, SciSearch ${ }^{\mathbb{B}}$, Current Contents ${ }^{\mathbb{B}} /$ Clinical Medicine,

Journal Citation Reports/Science Edition, EMBase, Scopus and the Elsevier Bibliographic databases. The manuscript management system is completely online and includes a very quick and fair peer-review system, which is all easy to use. Visit http://www.dovepress.com/ testimonials.php to read real quotes from published authors. 